\title{
Medial Bodies: Forays into Artistic and Philosophical- Anthropological Research
}

Martin Dornberg and Daniel Fetzner

The purpose of the present paper is to show how media artistic performances or installations deal- with topics and issues which can be understood as genuine contributions to the following questions: which entanglements can be noticed today between the body and media? How can these interweavings be understood or observed while using artistic installations? And what role is played by fictional or factual elements? In order to propose some answers to these questions the following projects shall be considered: the Intercorporeal Splits project cycle with three Skype performances and the artistic intervention BUZZ in an Indian insect laboratory. The presentation of these projects aims to show how the body gains new dimensions through artistic practices and how these dimensions reinvent the bodily structure. In this process of transformation fictional, factual, and factional elements contributing to the acts of reinvention shall be considered.

\section{The Intercorporeal Splits Research Cycle}

\subsection{Skype virtuality, embodiment, and the hybrid status of medial bodies}

Letters, telephone, and other communication channels: there are certainly many ways to communicate with other people at a distance. For a decade now, we have been making increasing use of digital live channels such as Skype, which does not only bridge distances but also creates new types of media interweaving. As in the cultural technique of telephoning, in this topology there is no longer a physical buffer between the here and the there. There is no in-between and certainly no measurable distance for an 'in-between' in mediatised space. The reduction of the "physical" in this space leads to a kind of "fictivisation" or "de-factualisation", due to its being less tangible.

The conceptual promises of a new immediacy of ubiquitous media from intelligent environments are insufficient-rather, we are currently dealing with an absolute prioritisation of mediation. Hence the question how the relationships be- 
tween the individual, the body, and the milieu emerge in a new way in the form of media and technical structures ${ }^{1}$ unfolds. From the perspective of the body turn and embodiment theories, these structure formations shall be understood as being eminently bodily/embodying, and as creating new "embeddings".

"Body turn" is an expression and promoter of significant cultural and technological changes of high relevance and current social images and ideas. How bodies are act-ually performed in real, social, literary and media terms is central to our current understanding of ourselves and the world and to the constitution of our identity. In such a context the media staging of physicality and the body has a particularly important status.

The three Skype performances mentioned in this paper, carried out from 2010 to $2013^{3}$, do not focus on the separating impulses of the acting subjects and their media. They rather pursue a radically media-ecological, body-related perspective. We investigate extended phenotypes ${ }^{4}$, caused by the continuous change of our organisms by means of electronic channels. Seen in this way, Skype does not connect separate persons and places. It rather contributes to the formation of common environments and embeddings through presence, experience of voice, skin and rhythm, among other things, and to generate a medial 'entanglement while using temporarily digital technology $y^{5}$

In the performances described in more detail below, what is established is not only a cognitive and/or emotive and/or musical connection between the interacting persons and the media used (music, techniques, materials, etc.). This process itself is understood by us as an eminently physical/embodying one and builds up a new "superpersonal", emergent, physical "third" reality between, and with the human and non-human actors involved. It builds a reality relevant, for instance, in hormonal, gestural, and medial terms, and hence materially relevant. For this reason we called this type of reality the "third body".

According to the central assumption of this article, the level of factuality in our projects refers not only to the "act-ual" actors of the performances ("things": artists, places, the Skype connection, digital algorhythms, the music, etc.), but

1 Erich Hörl, (2014). Tausend Ökologien. In Diedrich Diederichsen, Anselm Franke (Eds.). The Whole Earth. Kalifornien und das Verschwinden des Außen. Berlin: Sternberg Press.

2 Jörg Fingerhut et al., (2013). Philosophie der Verkörperung: Grundlage zu eineraktuellen Debatte. Berlin: Suhrkamp.

3 Daniel Fetzner \& Martin Dornberg, (2015). Intercorporeal Splits. Künstlerische Forschung zur Medialität von Stimme, Haut und Rhythmus, Leipzig: Open House. With articles by Jean-Luc Nancy, Klaus Theweleit, Georg Christoph Tholen and others. See www.metaspace.de/Main/ls

4 Richard Dawkins, (1982). The Extended Phenotype: The Gene as the Unit of Selection, Oxford: Freeman.

5 Martin Dornberg, (2014). Dritte Körper. Leib und Bedeutungskonstitution in Psychosomatik und Phänomenologie. In Arno Böhler, Christian Herzog, \& Alice Pechriggl (Eds.). Korporale Performanz. Zur bedeutungsgenerierenden Dimension des Leibes (pp. 107-127). Bielefeld: transcript. 
also to what is "done" (lat. factum) in a double sense of the word: what happens in the interaction between the imaginary/virtual worlds/bodies and the real bodies, and what act-ually really emerges, particularly through the newly created superpersonal common reality and its specific mediality. The status of the latter or of this new "thing" is, of course, a little more fragile, "ephemeral", than the factual status e.g. of the performer himself. ${ }^{6}$

All skype performances create partially invented worlds influenced by fictional elements, elements that have imaginary character. The performances "tell" about these imaginary worlds via their forms of realisation, transport them and/ or not only exhibit them in fact but also create hybrid forms of mediality and corporeality." "Body images"7 of people or human bodies in the field of mediality (e.g. mediated via video or Skype) interact with "body images" of people and human bodies in reality (of the participating artists and the audience). In this field of mutual de- and re-territorialisation ${ }^{8}$ the body gains a hybrid, transitional character "on both sides" of the interaction. ${ }^{9}$

\subsection{Three media ecological interventions-Intercorporeal Splits}

"Close to noise, chaos and deadly disorder new things arise."

Michel Serres

The Intercorporeal Splits project is divided into a cycle of three Skype performances and exhibitions. The translocal improvisation Voice viaviolin ${ }^{10}$ (VVV, 2010/11) generates third body experiences of two musicians of digital interphysicality. Peau/ $\mathrm{Pli}^{11}$ (PP, 2012) aims to develop and unfold reality shifts, transitions, and fluctu-

6 Martin Dornberg, (2020). Flüchtig und gestaltbar. Zur Zwischenleiblichkeit und Umweltbezogenheit "dritter Körper" im Ausgang von Experimenten mit der"zweigriffigen Baumsäge. In: Petra M. Meyer, (Hg.) (2018). Ephemer; München: Fink.

7 The term "body image" is defined differently in developmental psychology, psychoanalysis, psychosomatics, and philosophy (e.g. phenomenology). However, what is common among these definitions is that it is not about purely cognitive or emotional representations of the body, but about bodily/embodying processes that also play a role in incorporating the body and its interactions with the environment on a fundamental level, while also contributing towards its formation. Cf. Thomas Fuchs, (2009). Das Gehirn-ein Beziehungsorgan: Eine phänomenologisch-ökologische Konzeption. Stuttgart: W. Kohlhammer.

8 Gilles Deleuze \& Felix Guattari, (1997/2002). Tausend Plateaus: Kapitalismus und Schizophrenie. Berlin: Merve.

9 Denisa Butnaru, Introduction, in this volume.

10 Retrieved from http://vvv.metaspace.de

11 Retrieved from http://pp.metaspace.de 
ations between different urban situations by means of dance and signal-boosting electrodes. Finally, Embedded Phase Delay ${ }^{12}$ (EPD, 2012/13) is a performance on the Helmholtz phenomenon of the missing half-second $d^{13}$ between a dancer, a tabla player, and a musician who, with the help of his electronic equipment, revises the sounds coming in from the other locations and re-forms them.

On the theoretical level Intercorporeal Splits uses the environmental model of the biologist Jakob v. Uexküll ${ }^{14}$, the analyses of Gilles Deleuze, Félix Guattari, and Henri Lefebvre ${ }^{15}$ of such concepts as "plateau" and "rhythm", as well as the concept of "intercorporeality" of the phenomenologist Maurice Merleau-Ponty. ${ }^{16}$ In order to create a rhythmic-spatial multi-layered nature for the performances, the actors were embedded in an Indian insect laboratory, a Mediamarkt (electronics retailer) in South Baden in Germany, in the rhizomatic network of the megacity Cairo, as well as in a former workers' pub in Freiburg/Haslach (Germany).

According to Deleuze \& Guattari, rhythms are "born of constant transcodings out of chaos"17 and only become effective through links from one milieu into another. Through the medial interplay of improvisation artists via voice, skin and rhythm in the respectively created common environments, local "functional circuits" are set up with specific "temporal structures' ${ }^{18}$. These have an impact on the event as an induction of trance. This works precisely because Cairo has a completely different rhythm from Bangalore. The data connections oscillate differently from the micro-rhythms of the body, and the vocal cords oscillate differently from loudspeaker membranes.

The individual 'embeddings' experience an asynchronicity via the technomedial connection, while the artists' bodies expand kinaesthetically via improvisation into their field of media-ecological action. In this hyperlocal, but goal-orient-

12 Retrieved from http://epd.metaspace.de

13 Henning Schmidgen, (2010). Die Helmholtz-Kurven. Aufder Spur derverlorenen Zeit. Berlin: Merve.

14 Jakob von Uexküll, (1973). Theoretische Biologie. Frankfurt a. Main: Suhrkamp., and Jakob von Uexküll, (1980). Kompositionslehre der Natur. Ausgesuchte Texte. Frankfurt a. Main: Propyläen.

15 Gilles Deleuze \& Felix Guattari, (2004). Tausend Plateaus. Berlin: Merve. See also Henry Lefebrve, (2013). Rhythmanalysis: Space, Time and Everyday Life. London: Bloomsbury.

16 Maurice Merleau-Ponty, (1986). Das Sichtbare und das Unsichtbare: Gefolgt von Arbeitsnotizen. München: Fink., and Maurice Merleau-Ponty, (1966). Phänomenologie der Wahrnehmung. Berlin: De Gruyter.

17 Gilles Deleuze \& Felix Guattari, 1997/2002, p. 429.

18 Jakob von Uexküll, 1973. 
ed mediation ${ }^{19}$ through contexts of action a "current without beginning or end" 20 is created, generating an artistic-performative intercorporeality ${ }^{21}$ among actors.

The projects of Intercorporeal Splits open up and deal with both the musical or theatrical performance and the genuine body. This raises various theoretical and practical questions: how do proprioception, body feeling, and the sense of time and space of the persons involved change during the performances or during their physical embedding? How do beat, mood, tempo, breath, body performance, and the moving image develop in the medial in-between? How does consciousness 'experiment with time and space, and how do technical elements transform our physical being?

Time and mediality are not understood here as a linear flow; rather, they are a field of superimposed temporal structures and ecologies, continuously re-formed through discontinuous embodiments or milieu formations as the rhythms of a situation, a feeling, or a thought can obviously not be synchronised exactly. The body simply is not a metronome. Overlapping time and space windows open up a multitude of non-positionable spaces between event and perception. This is precisely why, despite or because of the artefacts of compression among actors, forms of digital intermediate corporeality arise in Skype encounters. Intercorporeal Splits investigates how the oscillating transmission gaps are experienced, with which experiences of interaction they are filled, and which medial ecologies arise in this milieus and how these can be theoretically grasped. ${ }^{22}$

The projects we developed create unstable and over-complex situations, some of which can only be mastered through play and improvisation. When a dancer rolls through public streets in an inflatable as an improvising city nomad and a

19 Martin Dornberg, (2013). Die zweigriffige Baumsäge: Überlegungen zu Zwischenleiblichkeit, Umweltbezogenheit und Überpersonalität. In Thiemo Breyer (Ed.), Grenzen der Empathie. Philosophische, psychologische und anthropologische Perspektiven, (pp. 239-259). Paderborn: Wilhelm Fink. And Martin Dornberg, (2014). Dritte Körper. Leib und Bedeutungskonstitution in Psychosomatik und Phänomenologie. In Arno Böhler, Christian Herzog, \& Alice Pechriggl (Eds.). Korporale Performanz. Zur bedeutungsgenerierenden Dimension des Leibes, (pp. 103-122). Bielefeld: transcript.

Gilles Deleuze \& Felix Guattari, 1997/2002, p. 41.

On this term cf. Merleau Ponty 1986, 1966, op. cit. and see below.

22 The research process of the three subprojects of Intercorporeal took place in five phases:

1. Embedding into medial and philosophical/anthropological discourses

2. Consolidation of actions in the form of live performances in urban situations

3. Reflection in the form of immediate subsequent conversations with the artists and the audience

4. Processing/treatment/folding of the medial material gained, for instance in university serminars and new projects or exhibitions.

5. Presentation and discussion of the results at specialist conferences on topics relating to artistic research and performative philosophy. Cf. Fetzner, Dornberg, 2015, pp. 209-222. 
violinist on a donkey cart moves through anarchic spaces of post-revolutionary Cairo, familiar orders and references inevitably fall to pieces. The newly created situations can be regarded as morphogenetic fields in which endo- and exo-conceptual 'signalling molecules' diffuse into the surrounding tissue and into all participants. The resulting media-ecological structure creates superpersonal, medial "third" physicalities ${ }^{23}$ Every cell in the body has sensory and effector functions, but how does the mediation between the material and the immaterial work? Which physicalities and medialities are used, created, and explorable? Function and control can hardly be spoken of here any more. One may find rather a 'pathic existence ${ }^{24}$ of acting subjects in a contingent environment.

A main method and artistic stylistic device of the three projects of Intercorporeal Splits is improvisation. It exposes the coexistence of all participants, the emergence of local medialities, and 'local ecologies'25. Their constitution becomes tangible and at the same time observable and explorable. In a tension (split) between success and failure, between participation and disruption, there are moments of environmental power ${ }^{26}$, which include all technical-medial, human, material, environmental actants on an eminently physical level. Through the artistic means of improvisation, it becomes possible to perceive sequences of genuine medial and physical participation on the one hand, and of the parasitic ${ }^{27}$, the interruption of affiliations and "participation without participation"28, on the other hand.

In relation to the question of faction and fiction at the core of this essay, the following can be stated: the projects generate a specific form of factuality since they also have a real character. They are experienced as a concert performance (VVV and EPD) or as a theatre performance (PP). In "Peau Pli" the imaginary el-

23 "Deleuze and Cuattari insist that the formation of territories is not a secondary product of basic drives (as Lorenz and others posit), but instead is its own explanation. They recognize that various functions (sexual, alimentary, aggressive, predatory) are organized within a territory, but no single function 'causes the territory to come into existence. Various functions 'are organized or created only because they are territorialized, and not the other way around. The T factor, the territorializing factor, must be sought elsewhere: precisely in the becoming-expressive of rhythm or melody, in other words, in the emergence of proper qualities (color, odor, sound, sillhouette)'. Ronald Bogue, (2009). A thousand Ecologies. In Bernd Herzogenrath (Ed.), Deleuze/Guattari \& Ecology, (pp. 42-56). New York: Palgrave Macmillan.

24 Victor von Weizsäcker, (2005). Pathosophie. Cesammelte Schriften Bd. 10. Göttingen: Vandenhoeck \& Ruprecht.

25 Erich Hörl, 2014.

26 Mark Hansen, (2009): Medien des 21. Jahrhunderts. In: Erich Hörl (Ed.), Die technologische Bedingung, (pp. 365-409). Berlin: Suhrkamp.

27 On this term: Michel Serres, (1981/1987). Der Parasit. Frankfurt a. Main: Suhrkamp. and das Projekt BUZZ, see below.

28 Erich Hörl, 2014, p. 130. 
ement is stronger: the dancer in the ball and the actor who reads philosophical texts while washing his feet are actually present, but they are hardly of an everyday nature and not suitable for everyday life. They cannot only be re-presented according to a logic of reality, depicted or questioned in terms of normal everyday logic and usability. This fictional element, or the play of colours between fiction and faction, is reinforced by the use of road space in PP. On the street there are not only dancers and spectators of the performance but also the dancer interacts with inhabitants of the district, who are on the street and who are not privy to the fictional/theatrical/invented event. They experience the performance unprepared, not as a theatrical, but as a real encounter. They interact with the dancer under the premises of their everyday life (as drivers of their own cars or by impacting directly with the dancer's ball) and thus create new facts-yet from the perspective of the performance, from its theatrical, fictional framework. Both levels change: fiction becomes faction. The real intervention of the young people at the end of PP even led to an injury of the dancer during the rolling down which was intended to end the performance. Here the fact of "intervention" ended the performance and led to a real change not only of the dancer and his health, but also of the theatrical situation. This ending (Lat. finis) effectively de-fined the performance as a faction. There are oscillations between fiction and faction.

The strength of the performances, however, is their hybrid status, which recreates actual elements in terms of faction. Even in the two performances, which "only" form a Skype concert (VVV, EPD), the real situations are interspersed with fictionalised/fictitious elements. Which musician makes music on a donkey cart in the midst of street noise (VVV) Who improvises via Skype in an insect lab with another musician and a dancer at the same time (EPD). The media folds-e.g. the images of tabla players and dancers at EPD-are transferred synchronously to the Mediamarkt and the chamber stage and alienated by mixing and superposing elements. In addition to a new actual status (emergence, formation of new superpersonal structures), they also gain new fictitious, imaginary elements: the location of the performances as their location and time formations cannot be compared with those of usual realities. They are hyper-local/u-topical and at the same time fleeting/ephemeral.They can only be assigned to a tertiary space, between factuality and fictionality. It becomes "only" a space of the performances. The resulting transitional microstructures formed between the space of "fiction" and "fact" cannot be clearly grasped, they can only be experienced. Borrowing the terminology of Deleuze and Guattari ${ }^{29}$, here we could speak of processes of de-and re-fictionalisation and de-and re-factualisation.

Oscillating between fictionality and factuality also corresponds to the improvisational character of all three performances. Improvisation combines the 
factual (sounds, rhythms, etc.) with imaginary/fictive/unreal elements (e.g. in dance or linguistic ideas). The improvisation process is always forward-looking, sometimes unplanned, and thus also permeated by virtuality. At the same time, improvisation creates new facts: the process itself, for instance the new musical collaboration of the music/musicians, and the resulting meeting of media, into which "place" and "time" signs (Deleuze/Uexküll) of the respective places also enter. New facts are created, a happening which has a certain out-come (like the injury) and so on. These facts can then also be captured, for example videographically (by picture, sound, and interviews). The resulting mixture of fictional and factual elements is then documented. ${ }^{30}$

\section{Corporeality and interface-media ecological mediators}

\subsection{Technologisation of the organic and hybrid bodies}

Our physicality, perception, and movement are increasingly conveyed in media-ecological terms today. The subjective body perception is integrated into the flow of technomedial feedback processes and into a new interplay of sensory and effector organs ${ }^{31}$. The body as interface between the medi $a^{32}$ and the linearly discursive physicality of writing are supplemented by altered third bodies and forms of technocyclic body perception. A central question of our projects and research is therefore which trans- and intermedial forms of physicality result from this, which "medialities of proximity" or which forms of place and space emerge, and which connection patterns between the different actors of these novel world networks become recognisable. In the three projects of Intercorporeal Splits, the above-mentioned practically and theoretically relevant media-ecological problem areas and phenomena and their physical references are selected as a topic, listed, exhibited, made observable, and put up for discussion with special consideration for body memory. The aim of the respective interventions is the generation of artistic, medial, theoretical, but also practical application-related emergences of meaning.

30 In order to research these structure formations scientifically and artistically, we use interactive web platforms and formats of interactive documenting (idocs). Cf. Daniel Fetzner \& Martin Dornberg, (2016). Partizipatives Parasitieren. Zum methodischen Potential interaktiver Webdokumentationen in der künstlerischen Forschung. In Oliver Fahle, Beate Ochsner, \& Anna Wiehl. Augenblick. Konstanzer Hefte zur Medienwissenschaft, 65 (66), 40-56. Marburg: Schüren Verlag. Retrieved from http://i-docs.org/2016/06/27/on-the-potential-of-interactive-web-documentaryfor-artistic-research

31 Jacob Von Uexküll, 1973.

32 Petra M. Meyer, 2008, pp. 286-296. 
These are also developed from observations, interviews, and usage analyses of the artistic interventions.

The three projects of Intercorporeal Splits show that media are mediators between people and things, and that they influence the physical and sensual experience of reality. In all media processes, experiences of intercorporeality are therefore also at work, where place ('oikos') and the emergence of its own peculiar times $^{33}$ are central. The omnipresence of mobile communication technologies and the penetration of everyday life with digital interfaces, as our projects show, result in paradigmatic changes in the human body and organic constitution: a changed anthropology. The increasing interweaving of human existence with digital processes and techno-facts leads, alongside a "technologisation of the organic" 34 to strains and compressions in the temporal experience of consciousness. These phenomena change not only the ideas, but also the nature of man and his physicality, which leads to dissonances in the subjective experience of space, time, and the ego. The "here" of the body and the "now" of the present are put into a new relationship. This creates transient zones of medial corporeality. ${ }^{35}$

We spend a lot of time in transmedial spaces. States of dislocation and phenomena of deterritorialisation are the result, and they challenge our capacity for integration and imagination in a new way. Staying in these imaginative spaces of action has effects not only on the emotional, but also on the physical experience of reality. The body as a medium of interpersonal encounter is increasingly interwoven with digital interfaces, which leads to changed relationship and patterns between man and his environment. The experiences of 'being to and in the world' and their media ecology can be shaped, designed, and controlled differently, creating new dependencies and interdependencies. In this context, as problematised in our projects, the human body develops new sensory and cultural techniques to embed itself in the rapidly changing world and the associated interdependencies in the media, which requires continuous adaptation processes.

We initially researched the phenomena of "intermediate corporeality" and the technomedial emergence of "third body" while using the phenomenology of Maurice Merleau-Ponty ${ }^{36}$. This was further based on a theoretical and practical experiment: the tree sawing experiments of Christian and Haas, two Heidelberg-based

33 Helga Nowotny, (1993). Eigenzeit. Entstehung und Strukturierung eines Zeitgefühls. Frankfurt a. Main: Suhrkamp.

34 Jutta Weber, (2003). Umkämpfte Bedeutungen: Naturkonzepte im Zeitalter der Technoscience, (p. 130). Frankfurt a. Main: Campus.

35 Faction is the contamination of the fact by fictional elements. We see it as a process, which is what our performances illustrate.

36 Maurice Merleau-Ponty, (1986). Das Sichtbare und das Unsichtbare: Gefolgt von Arbeitsnotizen. München: Fink., and Maurice Merleau-Ponty, (1966). Phänomenologie der Wahrnehmung. Berlin: De Gruyter. 
researchers in the working group of the general medicine doctor, psychosomaticist, and philosopher Victor v. Weizsäcker. In the experiment, two people work on a two-handled trim saw. Their movements are registered by an apparatus, the subjective experience of the participants is continuously queried, and the quantitative performance is also recorded. From these experiments, many conclusions can be drawn about successful interactions in the fields of communication and life processes. Successful performance results from successful coordination processes among each other and the type of task (the tree trunk or the sawing capacity). Feedback processes take place for all participants simultaneously through the entire process and the activity performed. The individuals, their bodies, and actions all merge with the overall event and performance to form a new whole: an overall body, which, as explained above, we named "the third body". ${ }^{37}$

What is new, emergent, and what motivates interaction in this case is the process of performance creation, or the process of interaction itself. This process and its procedural success are bodily-physically determined and by the character of the interacting media. What is new is not little predetermined and shows either partially or completely new properties. Thus corporeality-as it is explored in the improvisations of the three subprojects-is always embedded in different social, media, and technical environments in a polysystemic way and can only be adequately understood through the production of superpersonal, complex bodies of action, and their emergent "third-body character", but also through their "withdrawal", "diastasis, and differential character". ${ }^{38}$

\subsection{Third Body and Phenomenology}

Similar thoughts are currently being discussed in cognitive science, with research in the vicinity of the Heidelberg psychiatrist and philosopher Thomas Fuchs, having strongly influenced the present approach. According to Thomas Fuchs and Hanne De Jaegher ${ }^{39}$ the currently dominant cognitive and representation-oriented theories of social cognition should be replaced by an enactive, intersubjective, and participatory paradigm. Current theories of social cognition are mainly based on representativist foundations and understand the phenomena of human interaction and communication only in a reduced and deformed way. Rather, it is a question of starting from the interaction and coordination of two embodied actors or of processes of mutual incorporation and intercorporeality within which

37 See the previous footnote and Klaus Theweleit, (2007). Übertragung, Gegenübertragung, Dritter Körper: Zur Gehirnveränderung durch neue Medien. Köln: Flusser Lectures.

38 Bernhard Waldenfels, (2002). Bruchlinien der Erfahrung. Frankfurt a. Main: Surkamp.

39 Thomas Fuchs, \& Hanne De Jaegher, (2009). Enactive intersubjectivity: Participatory sense-making and mutual incorporation. In Phenomenol.Cogn.Sci., 8, 465-486. 
"the lived bodies of both participants extend and form a common intercorporality" (ibid., p. 465).

Fuchs and De Jaegher discuss that the intentions of both interaction partners and their bodies connect with each other, merging in a specific way with their respective environment and the intentions of the other. "Their body schemas and body experiences expand and, in a certain way, incorporate the perceived body of the other. This creates a dynamical interplay which forms a particular phenomenal basis of social understanding and which we will describe as mutual incorporation" (ibid., p. 472). They emphasise that this process of mutual incorporation not only interconnects the two bodies and consciousnesses of the interaction partners, but also forms specific larger units with the environment. "Incorporation is not restricted to that which is near the skin, however-the lived body extends to whatever object it is interacting with" (ibid., p. 473).

Similarly, how the blind person extends his body into the environment with his cane, which becomes an organ of relationship or touch, and the blind person no longer knows where his body or cane ends and the environment begins, the environment and its ability to act and form organs of perception is in turn transported via the cane, the air, sounds and other things into the blind person's organism (ibid., p. 472). Similar processes can also be found-according to Fuchs and De Jaegher-in sport, e.g. in tennis (ibid., p. 474).

Fuchs and De Jaegher emphasise that the joint interaction process develops its own embodying potency and its own emergent abilities to perceive and act on mediality: "The in-between becomes the source of the operative intentionality of both partners" (ibid., p. 476).

In their article, Fuchs and De Jaegher work on aspects of "bipersonal" or "trilogical" entities in relation to the operative intentionality they are looking forsimilarly to Christian and Haas $(1949)^{40}$ :

1. The processual logic becomes the source of the operational intentionality of both partners.

2. It can not only be attributed to one partner, but must also include value, target, and environmental and specific process variables.

3. The evolving capabilities of 'memorising' and 'acting' are related to each other and to the specific process and environmental variables.

4. The process logic gets a new, emergent quality, which is communicated to both interaction partners and is (thus also) operatively better available to them. Here a specific mediality is implied in and by the mutual relationship. 
In these enactive processes the bodies of the participants are central variables, components, and mediators and at the same time are the result and consequence of these "alogical" interactions that thwart any duality. Their emotions, moods, aspirations, and "body images" (co)constitute the involved medialities

\section{Chiasmatic medialities and corporealities of disturbance}

Our three projects, referred to in this part of the essay, are inspired both on a theoretical and practical level by Maurice Merleau-Ponty's later philosophy, and have been developed in the light of this in order to further differentiate it. Merleau-Ponty resolutely develops a philosophy of "intermediate corporeality" and understands the body as a "two-sheet being", which connects oneself not only with the other person, but also with the materiality of things and the world.Merleau-Ponty's concept of 'chiasm' describes in this context precisely the crossover through which the two sides of the sheet, body and world, are intertwined:

This mediation through reversal and this chiasm have the effect that there is not simply an antithesis of for oneself / for others, but that there is one being that contains all this in itself, first as sensual being and then as being without restriction [...]. Chiasm is not only exchange between me and others [...], it is also exchange between me and the world [...]: what begins as a thing ends as consciousness of the thing, and what begins as a 'state of consciousness' ends as a thing. (ibid., p. 274)

The intermediate corporeality between people, or between people and things is never unambiguous but saturated with negativity, susceptible to disturbance and injury, and diastatic/split. For this reason, Merleau-Ponty sees the invisible, for example, as something that is closely connected to seeing. Distance and invisibility are just as necessary for visibility as proximity. "Negativity [...], the untouchable of touching, the invisible of seeing [...] is the other side or the reverse side [...] of sensual being" (ibid., p. 321).

According to Merleau-Ponty, the body (which can both see and be seen) is the hinge (charnière) of this interaction, which Merleau-Ponty calls "flesh (chair)". In so far as nature is the other side of man, and the anonymous visible is realised by man, flesh forms the texture between things and human beings. The "flesh" is both the result and expression of this interweaving, this chiasm: "Where should we draw the line between body and world when the world is flesh?" (ibid., p. 182). Hence, things are an extension of my body, just as my body is an extension of the world. When Merleau-Ponty claims that the subject is made of the same material

41 Maurice Merleau-Ponty, (1968). The Visible and the Invisible. Evanston: Northwestern University Press. 
as the world, it means that we humans share our corporeality with things, for example our visibility but also invisibility.

Without being able to go further into Merleau-Ponty's theories here, one can ask in relation to the question of fictionality and factuality whether Merleau-Ponty's theory of chiasm does not point to existentially inherently fictional and factual elements in the experience/perception of reality. These are not exclusively related to the subject and its constructional achievements, an aspect which is also called negativity by Merleau-Ponty or by Sartre ${ }^{42}$, but also to the reality itself, its diversity and variety. As a result, the chiasm of man and the world is always saturated on the side of both subject and object with virtuality and constructedness. Faction is the contamination of the real by fictional elements. This can happen in different media: films, literary narratives, and skype performances in which entities, feelings, and atmospheres are contextually invented. The specificity of faction is precisely this: it breaks rules of the real.

Bernhard Waldenfels, has strongly emphasised the aspect of disturbance, 'diastasis and difference', in his entire oeuvre based on the works of Merleau-Ponty, Levinas, and Derrida. Each 'in between'-and this is also the subject of the three performances of Intercorporeal Splits - contains "processes of separation which are related to partings, isolation, and passing away" (Waldenfels, 2002, p. 175). On the one hand, these processes are temporal: "the shift gains a radically temporal sense when we simultaneously conceive the anteriority of an antagonism with the posteriority of the effect producing a response" (ibid., p. 178) and, on the other hand, to understand it spatially: "Shift means [...] that something or someone develops in the shift, so that the 'shifted impression' is never unified by a clear identification" (ibid., p. 179). Waldenfels speaks of a "time-space that is indicated in the union of diachrony and diatopia" (ibid., p. 180). Through the design of time and space, this interspace simultaneously possesses or generates its own medial and physical qualities and characteristics.

Based on the phenomena of disturbance, diastasis, and difference, our artistic and philosophical projects have in addition to the phenomenological insights approached the concept of "parasiting" and the work of Michel Serres ${ }^{43}$. The concept of disturbance is central and became the connecting research field of our two follow-up projects (see below). ${ }^{44}$ If the term "parasite" is applied to the three projects

42 Martin Dornberg, (1989). Gewalt und Subjekt: Eine kritische Untersuchung zum Subjektbegriffin der Philosophie J.P. Sartres. Würzburg: Königshausen \& Neumann.

43 Michel Serres, 1981/1987.

44 Martin Dornberg, (2017). Mitgeteilte und parasitäre Emergenz. Zwei Modelle verkörpernder Evolution. In Gregor Etzelmüller, Thomas Fuchs, \& Christian Tewes (Eds.), Verkörperung. Eine neue interdisziplinäre Anthropologie, (pp. 281-311). München: De Gruyter. and Martin Dornberg, \& Daniel Fetzner, (2017). Experimentelle Taktilität. Zur medienökologischen Erforschung von 
of Intercorporeal Splits, then they "parasitise" a social space, both materially and medially. They disturb, break through, boundaries and at the same time create new forms of embodiment, incentives, and intermediate bodies. All three projects also had to do directly with disturbances, performing, and investigating them. In the following we only mention the interruption of the Skype connection in "Voice via Violin", its real vulnerability in "Peau/Pli", and the question of delay or the possibility of connection in a diastatic space in "Embedded Phase Delay".

Michel Serres' parasitology, as shown below, develops a disturbance-related concept of physicality and mediality, as well as of the "third". This provides further possibilities of understanding and multiplication for our projects and for the question of the medial body and its relationship between fiction and faction. It is not the transmitter-receiver relationship which is fundamental for Serres, but that of communication and noise. Our projects and their understanding of body and mediality have thus changed through their own dynamics from a more success-oriented, results-oriented pole to a more complex, disturbance-oriented "parasitic" orientation. This and the related altered image of the body and its medialities will be further discussed with respect to two BUZZ projects following Intercorporeal Splits. These too embody the oscillation between fictional or invented, and factual elements and processes of their mutual re-territorialisation and de-territorialisation through installations, and help to clarify them conceptually/theoretically.

\subsection{BUZZ-Parasitic intervention in an Indian insect laboratory}

"Background noise is the basis of being, and parasitism is the basis of relationships."

Michel Serres (1980: 83)

The project Buzz-Parasitic Ecologies consisted of two parts: an intervention in a South Indian insect laboratory (2014) and a folding installation in Freiburg (2015). ${ }^{45}$ Both interventions focus on forms and concepts of the "parasitic", as developed primarily by Michel Serres

\section{Experimental system I-INFECTION/INTERVENTION (2014)}

In the summer of 2014, an artistic-media-ecological laboratory was built at the Indian Institute of Science (IISc) in Bangalore. The laboratory investigated embodiments, observation, and media practices of social insects and participatory mi-

Zwischenkörpern. In Karin Harasser (Ed.), Auf Tuchfühlung. Zur Medialität des Taktilen, (pp. 39-63). Frankfurt: Campus Verlag,

45 Daniel Fetzner \& Martin Dornberg, (2015). BUZZ—Parasitäre Ökologien. Freiburg. Retrieved from http://www.metaspace.de/buzz/zeitung.pdf 
crostructures of human and animal societies while using the South Indian wasp Ropalidia marginata as an example. The old wasp laboratory of the Centre for Ecological Sciences was converted into a temporary accommodation for BUZZ. Various formats such as Skype performances, installations, screenings, scientific experiments and discussions created interfaces between knowledge/theory, research practices, and art. The intervention saw itself as parasitic —and was also perceived as such on site, more precisely, as a transdisciplinary metamorphosis in which, on the one hand, knowledge productions are made observable, and, on the other, they were parasitised and created anew.

\section{Experimental system II-DISSEMINATION (2015)}

In cooperation with the Freiburg ethnographic film festival, the results of BUZZ were presented and discussed in an art gallery as part of a two-week assemblage.

A temporary insect laboratory was set up in the rooms of Gallery T66. A parasitic installation with a queen ant and three workers, visual connections and electroacoustic sounds produced interference, and a short-wave radio connection generated direct contacts with Bangalore, India. Video screenings, readings and performances with scientists and artists invited public discussion and transdisciplinary discussions.

Within the framework of Experimental System II, participatory processes of etho-ethnographic encounters were realised in which human and non-human forms of communication and sense production were staged and investigated with respect to their medial and ecological embeddings. Processes of life, mutual reference, environmental formation and embodiment were made sensually experienceable by overlapping artistic, scientific, and philosophical/anthropological approaches in which people, animals, things, theories, and media are involved in different ways and which fertilise and parasitise each other.

\subsection{Media as resonant milieux for the body and their animal dimensions}

In recent years, animals have been increasingly present media theory discourses, especially in the form of an ethological turn ${ }^{46}$ If media are understood as resonant milieux rather than techniques, 'animal' factors, namely atmospheric, environmental, and organismic factors, such as for instance rhythms, play a much more important role in their understanding. Parasitic, viral, and microbial strategies

46 Among others, Eva Johach, (2011). Andere Kanäle: Insektengesellschaften und die Suche nach den Medien des Sozialen. In Marie-Luise Angerer, \& Karin Harrasser (Eds.) ZfM, 4(1), 71-82., Niels Werber, (2011). Ameisengesellschaften: Eine Faszinationsgeschichte. Frankfurt a. Main: Fischer., cf. also in general $Z f M 4(1)$. 
can also serve to better understand media processes and their interaction with humans and their environment. ${ }^{47}$ Cultural things and media are conceived as 'quasi-objects ${ }^{48}$ and as 'cyborgs ${ }^{49}$. The contrasts between humans, animals and technology, nature and culture are shrinking. Environmental education, mediality, embodiment and the parasitic ${ }^{50}$ become central categories of a networked new culture of understanding.

Techniques can also be developed and applied by non-humans. Beavers build dams, termites build fantastic structures and algorithms interpret our behavior. These knowledge practices develop continuously in a variety of ways, are disseminated in a variety of ways, and as extended phenotypes ${ }^{51}$ become part of collective memories and multiple media ecologies. Of particular importance is the question of at what moments and in what form knowledge arises at all, how it is classified as such, to then finally (and yet simultaneously) to be conveyed in the media and ultimately embodied, materialised. The project cycle BUZZ-Parasitic Ecologies aims to investigate this question, make its microstructures observable and generate answers to it.

\subsection{Media as Anthropo-parasites}

Ethnography, art, philosophy/anthropology, psychotherapy, and biology have developed observation methods to trace one's own foreignness, one's own unconsciousness, and one's own genesis of meaning through dealing with the other and the foreign. They work with different methods on related questions. In spaces between art, science, and philosophy, new forms of pararasitic fertilisation processes of life, understanding and movement emerge. In this approach, the parasite is an important conceptual figure for providing orientation for artistic and epistemological intervention. The parasitic is envisaged as a living concept that helps to understand dimensions such as exchange, existence, life, science, thought, and art: just as the exchange between two beings can also be understood as parasiticsymbiotic and/or parasitic - and perhaps both sides pursue the same strategy. The term therefore needs other meanings. Their scientifically sensible strategic limitation runs the risk of failing to do justice to the transition between parasitism,

47 Jussi Parikka, (2010). Insect Media: An Archaeology of Animals and Technology. Minneapolis: University of Minnesota Press. Cf. the interview of the authors with Jussi Parikka in Fetzner \& Dornberg, 2015, p. 30.

48 Bruno Latour, (2014). Existenzweisen. Berlin: Suhrkamp.

49 Donna Haraway, (1991). A Cyborg Manifest., London: Routledge.

50 Michel Serres, 1981/1987, and for instance Lynn Margulis, (2018). Der symbiotische Planet oder Wie die Evolution wirklich verlief. Frankfurt a. Main: Westend. 
mutualism, and symbiosis. The parasite is always, at the same time, eminently physical, a material, thus not a purely spiritual figure. He realises bodily connections with specific media skills and qualities.

Media connections can per se be conceived as a form of an organic medial-parasitic connection. Post-Snowden media are co-evolutionary and parasitic: Pull technology is a hungry creature that devours its host-with the apps that live as ectoparasites on and under our skin. Only occasionally are they annoying to their host. The boundaries between symbiotic and parasitic media are fluid. In any case, they are of an animal quality. "Ambient media" not only change our perceptions and movements parasitically, but directly ("psychosomatically") change our physicality. Media matter. They not only transport the factual and the invented, but also form hybrids between these two dimensions by becoming part of everyday life.

Parasitic relationships also exist in art. What Hal Foster ${ }^{52}$ describes as an ethnographic turning point is experiencing an enormous acceleration in the production of art due to digitalisation and globalisation. Artistic interventions have developed their own aesthetic formats: Artists in residence travel around the world in a "parasitic" search for artistic prey for galleries and art markets. Essentially, this art tourism resembles medical and military operations of get in quickly, act fast, get out. This also describes BUZZ's strategy as an artistic parasite.

In epistemology, the same question applies to art and science: are parasites the basic element of a knowledge system or its pathology? Who or what parasitises whom? BUZZ parasitises the Indian Institute of Science, Gallery T66 and the ethnographische Filmforum in order to mutate as a form of serious knowledge production into artistic research, to form a new body. It is precisely by such a mutation that the corporeal structure affirms its mediality. Therefore, the parasite nests in different systems, e.g. in a wasp laboratory, in order to make changes there and to initiate new forms of perceptions and movements through disturbances. Without these new bodies and mediality levels, there are no new experiences and no new thought.

\section{The parasite from fiction to faction}

Serres relates the concept of the "parasite" to at least six different levels:

1. Parasites in the sense of real minute living creatures: real parasites.

2. Background noise (French Le parasite): these are interferences in the area of communication / media theory.

52 Hal Foster, (1996). The return of the Real. Boston: MIT Press. 
3. Parasite in the social/sociological sense: phenomena relating to e.g. economic phenomena of siphoning and exploitation.

4. Parasite/parasiting in the conceptual sense: each sense/concept has a part in other concepts in the chain of meaning, and shifts or parasitises these other concepts; each concept has a function of observation and therefore asks the question of the perspective, the outlook or the "direction" of the concept.

5. In the sense of theory of action: each intervention changes reality and at the same time must adapt to it at the same time. It creates something new, parasitises reality and at the same time is influenced / parasitised by the the latter in order to be able to bring about change at all.

6. In the "chiasmatic"-here levels 2-5 are involved: perception and movement, concepts and actions are incorporated in the interplay of mutual structure formation of exo-conceptual and endo-conceptual relations, of humans and the world, and of fiction and faction. The actors involved change, exploit, and "parasitise" each other.

Here the concept of the parasite is used as a "traveling concept ${ }^{\text {“53 }}$, which connects fictional and factual levels in different ways and thereby creates new conceptual and/or factual connections in other areas.

Art challenges different factual levels. The BUZZ project, for example, deals on one level with animals (social insects), but also with their parasites. The wasps and ants in the IICS are threatened by real parasites on the one hand, but on the other hand they use a wealth of parasites (as food, as a weapon of war against enemy species, etc.). At the same time, the art project was a kind of "parasite" in the local scientific community. We disrupted, changed, and questioned processes and routines. The laboratory was the "host" who was not only "inspired" by our changes, which were also real (bamboo installations, spatial changes, lectures, performances, etc.), but also influenced and to some extent "exploited".

Since our interventions connected and mixed all six of the above-mentioned levels of the parasitic, a process of reflection/change was initiated by the involved scientists: they were "parasitised" by our considerations, our real/factual intervention and not the least, by the concept of "parasite". They became more aware, for example, to what extent they were dependent on the wasps/ants they were researching and how they were in their turn influenced/"parasitised" by them. Through our intervention, the vector of observation/influence even reversed for the scientists involved: the insects changed from objects (of observation) to subjects (which influence research itself).

53 Birgit Neumann \& Ansgar Nünning, (2012). Travelling Concepts for the Study of Culture. Frankfurt a. Main: de Gruyter. 
Scientists also became more aware of the interventional nature of their actions. The question of the observer's perspective (hence including the perspective element of the concepts/ the research) was also more reflected on. At first, the concept of the parasite was relatively fictitious, not very common, and not very useful for some of those involved. It belonged only to a part of its own science or to a completely different field of reality or scientific/artistic field (sociology, communication theory, art, philosophy). By its "travelling", the concept of "parasite", suddenly became more real. Something could be learned about "it"/. Starting from an area remotely distanced from science, through real interventions and the use of a transdisciplinary discourse or a transdisciplinary experimental system ${ }^{54}$ and travelling concepts, something was learnt/modified in one's own discipline and factual elements were generated.

In fact, the scientists in India, but also the visitors to our exhibition in the T66, subsequently paid more attention to "real" parasites (level 1), understood disturbances as an opportunity (level 2), treated power relations (gender, caste, etc.) or different cultural influences more carefully (level 3), and paid more attention to the observer point of view and the aspect of change in theory and practice/action (levels 4-6).

\section{The medial body of performance art and its factographic potential}

In the media theoretical discussion, there are two major orientations which may be described as media marginalism and media fundamentalism. The first position refers to the secondary nature of media: "Starting from the transmission character of the medium, media are identified with the material conditions of realisation of drawing processes. Media transmit something that is not itself of the'nature' of a medium"

The opposite viewpoint is taken by media fundamentalism, which is based on the ineluctable a priori nature of the media. "Media thereby become the source of world production, the junction of our understanding of the world and self, and thus enter the void left behind by the erosion of the modern concept of subject." ${ }^{56}$

From our point of view and for the understanding of our projects, it is however crucial to remain open to both perspectives and to investigate their mutual areas of influence and parasitisation. Even when the transmission character of the me-

54 Hans-Jörg Rheinberger, (1997). Toward a History of Epistemic Things: Synthesizing Proteins in the Test Tube. Stanford: Stanford University Press.

55 Erika Ficher Lichte \& Christoph Wulf, (2004). Praktiken des Performativen, (p. 131). Berlin: Akademie. 
dium is emphasised (its "transparency" and "mediating power"), a fundamental "intransparency or subversion of the transmitted" 57 can always be observed ("opacity", "alteration"). Instead of searching for ultimate definitions of the medium/ mediality, we believe it is important to consider the concrete practices (practices, techniques, materials, etc.) through which media are formatted and used. "To use something means: to deal with something that we have not created ourselves in such a way that it is changed at the same time. Repetition and change go hand in hand in use. Practices have the power to 'follow' programs, patterns, rules, scripts by modifying them at the same time. In execution there is always an 'excess' over what is carried out". ${ }^{58}$

According to Georg Christoph Tholen, different meanings of medium, media, and mediality can be worked out in terms of conceptual history. ${ }^{59}$ On the one hand, media are means of conveying and passing on meaning, information, and messages between senders and recipients. On the other hand, however, media should be seen in their specific media-related momentum, "not as a passive tool or instrument, but as the constructive activity of an'in-between"” (ibid., p. 151). In this way, media form their own meanings and spaces and open up their own spectrum of differences. Here, a simpler media concept (which includes written characters, for example) is extended to a more complex one in which media increasingly develop their own specific staged or performative power.

When it is said that interaction processes such as sawing on the two-grip tree saw or microstructures of higher complexity such as language or Skype performances unfold their own mediality, reference is made to the fact that the superpersonal units of experience and behaviour, through and during their performance, generate specific feedback phenomena and their own bodily as well as medial "representation" and transformation processes.

As Christian \& Hass (1949) or Tholen (2005) argue, the superpersonal character of interactional-mechanical processes begins to differentiate itself from these references and their self-references. It partially detaches itself from them; and the new, detached, sometimes completely different processes intervene then in the "previous" ones, shaping them partly or completely.

Thinking about "intermediate corporeality" as well as understanding "media" is not only about "communication" or "interaction" and their spiritual, emotive, technical, or other elements, but also and especially about a process of reflecting on emergence.$^{60}$ It is about understanding how alterity, relationality, artificiality, and third parties are accomplished in the interaction or in and through superper-

57 Ibid.

58 Ibid.

59 Ceorg Christoph Tholen 2005, p. $150 \mathrm{ff}$.

60 Martin Dornberg, 2017. 
sonal bodies of action. The concepts of a medial or third body also aim to support this view. In doing so, emergence and affection do not develop only through "doing"/participation, but also through "leaving"/letting go, through the involvement and generation of specific textures of time and physicality.

Both in the tree sawing experiments and in our artistic projects, namely Intercorporeal Splits, human sensory perception and human behavior reorganise themselves, as well as the mediality in which they take place. The emergence of superpersonal "multilogical" systems of reference with their specific medialities leads to the "entanglement" ${ }^{\text {"61 }}$ of different spaces and intermediate bodies: that is it leads to the entanglement between a rather interphysical, interactive embodying pole on the one hand, and a differentiating medial, e.g. linguistic or technical pole, on the other.

The process of entanglement between interphysical-interactional space and the space of difference-generating artificiality and third space unfolds its own dynamics, generates its own abilities of "perception" and "movement" (Von Uexküll, 1973), of perception and affection, but also of time, movement, and transience. The exhibition at Galerie T66, which concludes the BUZZ project and this contribution, shows and stages precisely these processes of the entanglement ${ }^{62}$ of science, philosophy and art, fiction and faction. Larger-than-life-sized ants, virtual ants are similarly real, by their contextualised function, like their real "doubles" in the ant colony built in the $\mathrm{T}$ 66. Real parasites (in the insect hotel at the window of the gallery building) and their mechanical "counterparts" in the tree in front of the exhibition building interact with sono- and geodetic data. Probably also with the nerves and parasites in the body of visitors to the exhibition. Immersed in a field of biological, artistic, scientific and philosophical information (newspapers, lectures, performances, etc.), of factuality and fiction, visitors are formatted, influenced and "parasitised" by these references, participating in this field of mutual influences, where media, human and non-human beings, things and actions constantly parasitise each other.

\section{References}

Christian, Paul, \& Haas, Renate (1949). Wesen und Formen der Bipersonalität. Stuttgart: Enke.

Dawkins, Richard (1982). The Extended Phenotype: The Gene as the Unit of Selection. Oxford: Freeman.

61 Gernot Böhme, (2010). Der Raum leiblicher Anwesenheit und der Raum als Medium der Darstellung, In: ]ürgen Hasse et al. (Eds.), Gelebter, erfahrener und erinnerter Raum, (p. 54). München: Albunea.

62 Retrieved from http://www.metaspace.de/Dokumentation/Buzz 
Deleuze, Gilles \& Guattari, Felix (1997/2002). Tausend Plateaus: Kapitalismus und Schizophrenie. Berlin: Merve.

Dornberg, Martin (1989). Gewalt und Subjekt: Eine kritische Untersuchung zum Subjektbegriffin der Philosophie J.P. Sartres. Würzburg: Königshausen \& Neumann.

Dornberg, Martin (2013). Die zweigriffige Baumsäge: Überlegungen zu Zwischenleiblichkeit, Umweltbezogenheit und Überpersonalität. In Thiemo Breyer (Ed.), Grenzen der Empathie. Philosophische, psychologische und anthropologische Perspektiven, (pp. 239-259). Paderborn: Wilhelm Fink.

Dornberg, Martin (2014). Dritte Körper. Leib und Bedeutungskonstitution in Psychosomatik und Phänomenologie. In Arno Böhler, Christian Herzog, \& Alice Pechriggl (Eds.). Korporale Performanz. Zur bedeutungsgenerierenden Dimension des Leibes, (pp. 107-127). Bielefeld: transcript.

Dornberg, Martin (2017). Mitgeteilte und parasitäre Emergenz. Zwei Modelle verkörpernder Evolution. In Gregor Etzelmüller, Thomas Fuchs, \& Christian Tewes (Eds.), Verkörperung. Eine neue interdisziplinäre Anthropologie, (pp. 281-311). München: De Gruyter.

Dornberg, Martin (2020). Flüchtig und gestaltbar. Zur Zwischenleiblichkeit und Umweltbezogenheit "dritter Körper" im Ausgang von Experimenten mit der "zweigriffigen Baumsäge". In Petra M. Meyer (Hg.): Ephemer. München: Fink.

Dornberg, Martin, \& Fetzner, Daniel (2017). Experimentelle Taktilität. Zur medienökologischen Erforschung von Zwischenkörpern. In Karin Harasser (Ed.), AufTuchfühlung. Zur Medialität des Taktilen, (pp. 39-63). Frankfurt a. Main: Campus Verlag.

Fetzner, Daniel, \& Dornberg, Martin (2015). Intercorporeal Splits. Künstlerische Forschung zur Medialität von Stimme, Haut und Rhythmus. Leipzig: Open House. With articles by Jean-Luc Nancy, Klaus Theweleit, Georg Christoph Tholen and others.

www.metaspace.de/Main/Is (accessed 05/05/2018).

Fetzner, Daniel, \& Dornberg, Martin (2015). BUZZ_Parasitäre Ökologien. Freiburg Retrieved from http://www.metaspace.de/buzz/zeitung.pdf (accessed 01/05/2015).

Fetzner, Daniel, Dornberg, Martin (2016). Partizipatives Parasitieren. Zum methodischen Potential interaktiver Webdokumentationen in der künstlerischen Forschung. In Oliver Fahle, Beate Ochsner, \& Anna Wiehl. Augenblick. Konstanzer Hefte zur Medienwissenschaft, 65(66), 40-56. Marburg: Schüren Verlag.

Fingerhut, Jörg et al., (2013). Philosophie der Verkörperung: Grundlage zu einer aktuellen Debatte. Berlin: Suhrkamp.

Ficher Lichte, Erika, Wulf Christoph, (2004). Praktiken des Performativen. Berlin: Akademie.

Foster, Hal (1996). The return of the Real. Boston: MIT Press. 
Fuchs, Thomas (2009). Das Gehirn—ein Beziehungsorgan: Eine phänomenologisch-ökologische Konzeption. Stuttgart: W. Kohlhammer.

Fuchs, Thomas \& De Jaegher, Hanne (2009). Enactive intersubjectivity: Participatory sense-making and mutual incorporation. In: Phenomenol.Cogn.Sci., 8, 465-486.

Hansen, Mark (2009). Medien des 21. Jahrhunderts. In Erich Hörl (Ed.), Die technologische Bedingung, (pp. 365-409). Berlin: Suhrkamp,

Haraway, Donna (1991). A Cyborg Manifesto. London: Routledge.

Hörl, Erich (2014). Tausend Ökologien. In Diedrich Diederichsen, Anselm Franke (Eds.), The Whole Earth. Kalifornien und das Verschwinden des Außen. Berlin: Sternberg Press.

Johach, Eva (2011). Andere Kanäle: Insektengesellschaften und die Suche nach den Medien des Sozialen. In Marie-Luise Angerer, \& Karin Harrasser (Eds.). ZfM, 4(1), 71-82.

Latour, Bruno (2014). Existenzweisen. Berlin: Suhrkamp.

Margulis, Lynn (2018). Der symbiotische Planet oder Wie die Evolution wirklich verlief. Frankfurt a. Main: Westend.

Merleau-Ponty, Maurice (1966). Phänomenologie der Wahrnehmung. Berlin: De Gruyter.

Merleau-Ponty, Maurice (1986). Das Sichtbare und das Unsichtbare: Gefolgt von Arbeitsnotizen. München: Fink.

Meyer, Petra M. (2008). Der Körper als Interface zwischen den Medien im Gegenwartstanz. In: Hajo Kurzenberger und Annemarie Matzke. TheorieTheaterPraxis, (pp. 286-296). Berlin: Theater der Zeit.

Nowotny, Helga (1993). Eigenzeit. Entstehung und Strukturierung eines Zeitgefühls. Frankfurt a. Main: Suhrkamp.

Neumann, Birgit, \& Nünning, Ansgar (2012). Travelling Concepts for the Study of Culture, Frankfurt a. Main: de Gruyter.

Parikka, Jussi (2010). Insect Media: An Archaeology of Animals and Technology. Minneapolis: University of Minnesota Press.

Rheinberger, Hans-Jörg (1997). Toward a History of Epistemic Things: Synthesizing Proteins in the Test Tube, Stanford. Stanford University Press.

Schmidgen, Henning (2010). Die Helmholtz-Kurven. Auf der Spur der verlorenen Zeit. Berlin: Merve.

Serres, Michel (1981/1987). Der Parasit. Frankfurt a. Main: Suhrkamp.

Tholen, Georg Christoph (2005). Medium, Medien. In: Alexander Roesler und Bernd Stiegler (Hrsg.): Grundbegriffe der Medientheorie. (pp. 150-172). Paderborn: Fink.

Theweleit, Klaus (2007). Übertragung, Gegenübertragung, Dritter Körper: Zur Gehirnveränderung durch neue Medien. Köln: Flusser Lectures.

Von Uexküll, Jakob (1973). Theoretische Biologie. Frankfurt a. Main: Suhrkamp. 
Von Uexküll, Jakob (1980). Kompositionslehre der Natur. Ausgesuchte Texte. Frankfurt a. Main: Propyläen.

Von Weizsäcker, Victor (2005). Pathosophie. Gesammelte Schriften Bd. 10. Göttingen: Vandenhoeck \& Ruprecht.

Waldenfels, Bernhard (2002). Bruchlinien der Erfahrung. Frankfurt a. Main: Surkamp.

Weber, Jutta (2003). Umkämpfte Bedeutungen: Naturkonzepte im Zeitalter der Technoscience. Frankfurt a. Main: Campus

Werber, Niels (2011). Ameisengesellschaften: Eine Faszinationsgeschichte. Frankfurt a. Main: Fischer. 